\title{
HYDRA LERNEJSKA, CZYLI O BRAKU MOŻLIWOŚCI POGODZENIA WYROKU TRYBUNAEU KONSTYTUCYJNEGO Z INSTYTUCJĄ KLAUZULI PRZECIWKO UNIKANIU OPODATKOWANIA
}

\section{WSTĘP}

Przedmiotem artykułu jest ocena obowiąującej klauzuli przeciwko unikaniu opodatkowania w świetle wyroku Trybunału Konstytucyjnego z 11 maja 2004 r. ${ }^{1}$ Teza artykułu sprowadza się do konstatacji, że hipoteza normy obecnie obowiąującej klauzuli przeciwko unikaniu opodatkowania nie spełnia kryteriów konstytucyjności tej instytucji postawionych przez TK. Polem badawczym będą trzy materialnoprawne przesłanki zastosowania klauzuli przeciwko unikaniu opodatkowania i próby ich dookreślania podejmowane przez ustawodawcę podatkowego, określone w art. 119a ust. 1 w zw. z art. 119c i 119d Ordynacji podatkowej ${ }^{2}$ w brzemieniu nadanym ustawą z 23 października 2018 r. o zmianie ustawy o podatku dochodowym od osób fizycznych, ustawy o podatku dochodowym od osób prawnych, ustawy Ordynacja podatkowa oraz niektórych innych ustaw ${ }^{3}$. Dodatkowo w celu uwypuklenia problematyki badawczej obecnie obowiązujące przepisy zostanę zestawione z pierwotną wersją klauzuli w brzmieniu nadanym ustawa z 13 maja 2016 r. o zmianie ustawy - Ordynacja podatkowa oraz niektórych innych ustaw ${ }^{4}$. W badaniach zostana zastosowane metody dogmatycznoprawna i prawnoporównawcza.

\footnotetext{
${ }^{1}$ Wyrok TK z 11 maja 2004 r., K 4/03, OTK ZU 2004, nr 5A, poz. 41.

${ }^{2}$ Ustawa z 29 sierpnia 1997 r. Ordynacja podatkowa, t.jedn.: Dz. U. 2019, poz. 900 (dalej jako: Ord. podat.).

${ }^{3}$ Ustawa z 23 października 2018 r. o zmianie ustawy o podatku dochodowym od osób fizycznych, ustawy o podatku dochodowym od osób prawnych, ustawy - Ordynacja podatkowa oraz niektórych innych ustaw, Dz.U. 2018, poz. 2193 (dalej jako: ustawa modyfikująca klauzulę przeciwko unikaniu opodatkowania).

${ }^{4}$ Ustawa z 13 maja 2016 r. o zmianie ustawy - Ordynacja podatkowa oraz niektórych innych ustaw, Dz. U. 2016, poz. 846 (dalej jako: ustawa wprowadzająca klauzulę przeciwko unikaniu opodatkowania).
} 


\section{WARUNKI KONSTYTUCYJNOŚCI KLAUZULI PRZECIWKO UNIKANIU OPODATKOWANIA W ŚWIETLE ORZECZENIA TK}

Ustawą z 12 września 2002 r. o zmianie ustawy - Ordynacja podatkowa oraz o zmianie niektórych innych ustaw ${ }^{5}$ przez dodanie do ustawy Ordynacja podatkowa art. $24 \mathrm{~b}$ do polskiego porządku prawnego została wprowadzona pierwsza klauzula przeciwko unikaniu opodatkowania. Zgodnie z art. 24b $\S 1$ Ord. podat. organy podatkowe i organy kontroli skarbowej, rozstrzygając sprawy podatkowe, miały pominąc skutki podatkowe czynności prawnych, jeżeli udowodniły, że z dokonania tych czynności nie można było oczekiwać innych istotnych korzyści niż wynikające $\mathrm{z}$ obniżenia wysokości zobowiązania podatkowego, zwiększenia straty, podwyższenia nadpłaty lub zwrotu podat$\mathrm{ku}$. W ramach nowej instytucji przewidziano również mechanizm recharakteryzacji czynności w art. $24 \mathrm{~b} \S 2$ Ord. podat.

Klauzula przeciwko unikaniu opodatkowania została szybko zakwestionowana przez Prezesa Naczelnego Sądu Administracyjnego oraz Rzecznika Praw Obywatelskich, na których wniosek TK ${ }^{6}$ uznał art. 24 b $§ 1$ Ord. podat. za niezgodny z art. $2 \mathrm{w}$ związku z art. $217 \mathrm{Konstytucji}^{7}$. Trybunał wprawdzie jasno stwierdził, że „nie budzi zastrzeżeń konstytucyjnoprawnych samo zjawisko normatywnej reakcji prawodawcy [...], także jeżeli przybrałaby ona postać "ogólnej normy obejścia prawa podatkowego«. Każda taka reakcja respektować jednak winna konieczne wymogi konstytucyjne, związane z poszanowaniem praw i wolności podatników".

Trybunał Konstytucyjny postawił trzy podstawowe warunki uznania klauzuli przeciwko unikaniu opodatkowania za zgodna z Konstytucją RP:

- przesłanki rozumienia (interpretacji) danego zwrotu niedookreślonego nie powinny być determinowane elementami subiektywnymi. Im większe pole do zindywidualizowanej interpretacji danego pojęcia, tym większa też groźba nieprzewidywalności rozstrzygnięć podejmowanych na jego podstawie;

- wykorzystywaniu zwrotów niedookreślonych powinna towarzyszyć konieczność nadania im takiej treści, która zagwarantuje jednolitość linii orzeczniczej (decyzji stosowania prawa);

- ustalenie treści pojęć nieostrych zastosowanych w danej regulacji nie powinno stać się udziałem organów stosujących te przepisy, co prowadzić miałoby w konsekwencji do niedozwolonego prawotwórstwa ze strony tych organów.

Brak klauzuli przeciwko unikaniu opodatkowania wiązał się z narastajacymi problemami wewnętrznymi i zewnętrznymi. W ujęciu krajowym nasilało się zjawisko unikania opodatkowania wynikające m.in. z agresywnego planowania podatkowego, którego jednym z istotnych powodów był brak omawianej

${ }^{5}$ Ustawa z 12 września 2002 r. o zmianie ustawy - Ordynacja podatkowa oraz o zmianie niektórych innych ustaw, Dz. U. 2002, Nr 169 poz. 1387.

${ }^{6}$ Wyrok TK z 11 maja 2004 r., K 4/03, OTK ZU 2004, nr 5A, poz. 41.

7 Konstytucji Rzeczypospolitej Polskiej z 2 kwietnia 1997 r., Dz. U. 1997, Nr 78, poz. 483 ze zm. (dalej jako: Konstytucja RP). 
klauzuli ${ }^{8}$. Z kolei na poziomie UE i OECD pojawiała się coraz większa presja na wprowadzenie do poszczególnych porządków prawnych klauzuli przeciwko unikaniu opodatkowania. Wstępnie przybrała ona formę Zalecenia Komisji z 6 grudnia 2012 r. w sprawie agresywnego planowania podatkowego ${ }^{9}$, a następnie dyrektywy Rady z 12 lipca 2016 r. ustanawiającej przepisy mające na celu przeciwdziałanie praktykom unikania opodatkowania, które mają bezpośredni wpływ na funkcjonowanie rynku wewnętrznego ${ }^{10}$. Presja zewnętrzna wiązała się nie tylko z globalna tendencją do walki z agresywnym planowaniem podatkowym, ale również przeciwdziałaniem szkodliwej konkurencji podatkowej ze strony państw, które nie przyjęłyby przepisów przeciwdziałających nadużyciu prawa podatkowego.

\section{MODELE KLAUZULI PRZECIWKO UNIKANIU OPODATKOWANIA W OBCYCH PORZĄDKACH PRAWNYCH}

Klauzule przeciwko unikaniu opodatkowania funkcjonują w innych porządkach prawnych od wielu lat, przykładowo w Nowej Zelandii od roku 1878 r., Australii - 1879, Niemczech - 1919, Francji - 1919, Chinach - 2008 czy w Wielkiej Brytanii - $2013^{11}$. Pomimo wspólnego celu, jakim jest przeciwdziałanie unikaniu opodatkowania, klauzule w poszczególnych porządkach prawnych przyjmuja różnorakie założenia konstrukcyjne. Za przykład moga posłużyć dwa odmienne modele klauzuli przeciwko unikaniu opodatkowania: niemiecki - oparty na koncepcji kwalifikowanego nadużycia prawa podmiotowego, oraz brytyjski - oparty na konstrukcji naruszenia normatywnego standardu racjonalnego działania ${ }^{12}$.

Zgodnie z $§ 42$ ust. 1 niemieckiej Ordynacji podatkowej ${ }^{13}$ nie jest możliwe obejście prawa podatkowego przez nadużycie możliwości kształtowania prawa. $\mathrm{W} \S 42$ ust. 2 tej ustawy zdefiniowano, że nadużycie występuje, jeżeli wybrano nieodpowiednią formę prawna, która w porównaniu z odpowiednia forma prawna prowadzi do nieprzewidzianych przez prawo korzyści podatkowych podatnika lub osób trzecich. Nie obejmuje to sytuacji, gdy podatnik wykaże

8 Por. raporty odnoszące się do luki podatkowej w podatkach dochodowych, np. Piekarz, Miarkowski (2015); Dover et al. (2015); Bąkowska, Gniazdowski, Lachowicz (2019).

9 Zalecenia Komisji z 6 grudnia 2012 r. w sprawie agresywnego planowania podatkowego, 2012/772/UE (dalej jako: Zalecenie Komisji).

${ }^{10}$ Dyrektywa Rady (UE) 2016/1164 z 12 lipca 2016 r. ustanawiająca przepisy mające na celu przeciwdziałanie praktykom unikania opodatkowania, które mają bezpośredni wpływ na funkcjonowanie rynku wewnętrznego, Dz. Urz. UE L 193, 19.07.2016: 1-14 (dalej jako: dyrektywa ATA).

11 Golecki (2018): 119.

12 Szerzej na temat niemieckiej i brytyjskie klauzuli zob.: Olesińska (2013): 107-123, 229243; Golecki (2018): 124-133.

13 Abgabenordnung, BGBl. I S. 3866, t.jedn.: 2003 ze zm. <https://www.gesetze-im-internet. de/ao_1977/_42.html, 5.05.2020> (dalej jako: niemiecka Ord. podat.). 
pozapodatkowe powody zastosowania danej formy prawnej, przy uwzględnieniu wszystkich okoliczności sprawy.

W Niemczech klauzula zostanie więc zastosowana, gdy wystapi nadużycie możliwości kształtowania prawa („Missbrauch von rechtlichen Gestaltungsmöglichkeiten”). Nadużycie wystapi w sytuacji, w której spełni się pozytywna przesłanka polegajaca na zastosowaniu nieodpowiedniej formy prawnej (,unangemessene rechtliche Gestaltung”) oraz uzyskania korzyści podatkowej nieprzewidzianej przez prawo (,gesetzlich nicht vorgesehenes Steuervorteil"). Równolegle warunkiem zastosowanie klauzuli jest brak spełnienia się przesłanki negatywnej polegającej na wykazaniu przez podatnika istnienia pozapodatkowych powodów zastosowania danej formy prawnej (,wenn der Steuerpflichtige für die gewählte Gestaltung außersteuerliche Gründe nachweist").

Konstrukcja klauzuli przeciwko unikaniu opodatkowania w Wielkiej Brytanii jest treściowo zdecydowanie bardziej złożona od niemieckiej ${ }^{14}$. Klauzula ma przeciwdziałać uzgodnieniom podatkowym stanowiącym nadużycie prawa. Uzgodnieniami podatkowymi są rozwiązania, co do których można w sposób racjonalny wywnioskować, mając na względzie wszelkie okoliczności, iż uzyskanie korzyści podatkowych było głównym lub jednym z głównych celów takiego uzgodnienia. Oznacza to, że uzasadnienie uzyskania korzyści podatkowych musi być oceniane z perspektywy rozsądnego obserwatora (reasonability test). Przez pryzmat standardu racjonalności oceniane będzie nie tylko zaistnienie uzgodnienia podatkowego, ale również wystapienie nadużycia podatkowego. Angielski ustawodawca zdecydował się na sformułowanie definicji nadużycia prawa przez wskazanie katalogu otwartego sytuacji, które moga stanowić to nadużycie, jak: sprzeczność z celem przepisów, sztuczność czynności czy wykorzystywanie luk w przepisach.

\section{KLAUZULA PRZECIWKO UNIKANIU OPODATKOWANIA W ŚWIETLE REGULACJI EUROPEJSKICH}

Pierwsze wytyczne dotyczący implementacji do krajowych porządków prawnych klauzuli ogólnej przeciwko unikaniu opodatkowania zostały wydane przez Komisję Europejską w formie Zalecenia Komisji. Zalecenie Komisji stało się podstawą do przygotowania klauzuli przeciwko unikaniu opodatkowania w brzemieniu nadanym przez wprowadzająca ją ustawę. Charakterystycznymi elementami tej klauzuli są m.in. nieuwzględnianie uzgodnień przyjętych w „zasadniczym” celu uniknięcia opodatkowania oraz wymóg kumulatywnego spełnienia przesłanek podważenia „przedmiotu, ducha i celów przepisów podatkowych" (pkt 4.2 i 4.5 Zalecenia Komisji).

Kolejnym krokiem legislacyjnym było zobowiązanie państw członkowskich do przyjęcia przepisów ogólnych przeciwko unikaniu opodatkowania. Klau-

14 Finance Act 2013, rozdz. 29, sekcja 206-209<http://www.legislation.gov.uk/ukpga/2013/29/ section/206> [dostęp: 5.05.2020]. 
zula ogólna uregulowana w art. 6 dyrektywy ATA ma charakter bardziej rygorystyczny od tej określonej w Zaleceniu Komisji. Po pierwsze, z klauzuli $\mathrm{w}$ brzemieniu uregulowanym w dyrektywie ATA wynika, że do jej zastosowania wystarczające jest, aby uzyskanie korzyści podatkowej nie było „zasadniczym celem” uzgodnienia, a wyłącznie „głównym celem lub jednym z głównych celów”. Ponadto uzyskanie korzyści podatkowej musi być sprzeczne „z przedmiotem lub celem mającego zastosowanie prawa podatkowego" w miejsce sprzeczności z „przedmiotem, duchem i celami przepisów podatkowych”. Polska klauzula przeciwko unikaniu opodatkowania wprowadzona ustawą modyfikująca klauzulę przeciwko unikaniu opodatkowania częściowo podąża za zmianami wynikajacymi z dyrektywy ATA.

\section{HIPOTEZA NORMY KLAUZULI PRZECIWKO UNIKANIU OPODATKOWANIA}

Obecnie obowiązująca klauzula przeciwko unikaniu opodatkowania uregulowana jest w art. 119a Ord. podat., zgodnie z którym, aby uznać czynność za unikanie opodatkowania i odmówić podatnikowi korzyści podatkowej, spełnione muszą zostać trzy przesłanki:

- osiagnięcie korzyści podatkowej było głównym lub jednym z głównych celów jej dokonania;

- osiagnięcie korzyści podatkowej jest sprzeczne w danych okolicznościach z przedmiotem lub celem ustawy podatkowej lub jej przepisu;

- sposób działania był sztuczny.

W brzemieniu nadanym ustawą wprowadzająca klauzulę przeciwko unikaniu opodatkowania trzy przesłanki zawarte w hipotezie normy kształtowały się następująco:

- czynność została dokonana przede wszystkim w celu osiagnięcia korzyści podatkowej;

- korzyść podatkowa była sprzeczna w danych okolicznościach z przedmiotem i celem przepisu ustawy podatkowej;

- sposób działania był sztuczny.

W celu realizacji wyżej wspomnianych wytycznych TK dwie z powyższych przesłanek dookreślono w art. 119c Ord. podat. oraz 119d Ord. podat. W dalszej części tekstu analizie zostaną poddane powyższe przesłanki zarówno w ramach obowiązującego stanu prawnego, jak i w ich pierwotnej formie, co pozwoli lepiej zobrazować trudności związane z realizacją wyroku trybunalskiego.

\section{PRZESŁANKA GŁÓWNEGO CELU DZIAŁANIA}

Zarówno przesłanka zastosowania klauzuli w jej pierwotnym brzemieniu („Czynność dokonana przede wszystkim w celu osiagnięcia korzyści podatko- 
wej”), jak i w brzemieniu obowiązującym (osiągnięcie korzyści podatkowej było głównym lub jednym z głównych celów dokonania czynności) budziły od samego początku liczne wątpliwości zarówno w literaturze krajowej ${ }^{15}$, jak i literaturze światowej ${ }^{16}$ na tle tego i podobnych rozwiązań. Zmianę wprowadzoną ustawą modyfikująca klauzulę przeciwko unikaniu opodatkowania uzasadniano implementacją dyrektywy ATA, która ma stawiać wyższy „próg” zastosowania klauzuli przeciwko unikaniu opodatkowania ${ }^{17}$.

Dla przedmiotu niniejszych rozważań istotniejsze są jednak próby dookreślenia rzeczonej przesłanki w art. 119d Ord. podat. W pierwotnej wersji art. 119d Ord. podat. czynność uznawano za podjęta przede wszystkim w celu osiągnięcia korzyści podatkowej, gdy pozostałe cele ekonomiczne lub gospodarcze czynności wskazane przez podatnika należy uznać za mało istotne. Tym samym ustawodawca sprecyzował zwrot niedookreślony, dokonując zamiany sformułowania „przede wszystkim” na „mało istotne” oraz dodając dwa synonimiczne pojęcia niedookreślone: „cele ekonomiczne” i „cele gospodarcze" 18 .

Wraz z nowelizacją art. 119a ust. 1 Ord. podat. wprowadzająca przesłankę celu głównego zmieniono również art. 119d Ord. podat. Obecnie dookreśla się, że przy ocenie, czy osiagnięcie korzyści podatkowej było głównym lub jednym z głównych celów dokonania czynności, bierze się pod uwagę cele ekonomiczne czynności wskazane przez stronę. W uzasadnieniu projektu ustawy nie wskazano, dlaczego zrezygnowano z rozróżnienia na cele ekonomiczne i gospodarcze, co jest frapujące w kontekście pozostawienia w mocy podobnego rozróżnienia w art. $119 \mathrm{c} \S 2$ pkt 2 Ord. podat.

Próby dookreślenia podjęte w art. 119d Ord. podat., zarówno w jego pierwotnym, jak i obecnie obowiązującym brzmieniu, sprowadziły się do pomnażania liczby zwrotów niedookreślonych. Wartością niedookreślenia pewnych pojęć w tym przypadku jest możliwość ich wykładni w świetle ustalonych doktryn orzeczniczych i naukowych, które odwołują się do celów ekonomicznych czynności. Wysłowienie ich $\mathrm{w}$ przepisie stawia interpretatora $\mathrm{w}$ zupełnie innym położeniu i każe postawić pytanie: co jeśli obok celów ekonomicznych (i gospodarczych?) podatnik kieruje się innymi celami, np. społecznymi czy dobroczynnymi? ${ }^{19}$ Wydaje się więc, że próba dookreślenia w art. 119d Ord. podat. nie powiodła się i stała się przyczyną kolejnych wątpliwości interpretacyjnych.

15 Por. uwagi na tle klauzuli PPT: Majdowski (2017): 26; Sołtysiak, Boniecka (2018): 48.

${ }_{16}$ Por. uwagi na tle europejskiego modelu klauzuli przeciwko unikaniu opodatkowania i klauzuli PPT: Bergmans (2016): 345-347; Moreno (2017): 444-446; Lang (2015): 659; Taboada (2015): 604, 607.

17 Uzasadnienie projektu ustawy, druk nr 2860, Sejm VIII Kadencji: 57.

18 Więcej na temat wątpliwości na gruncie tej przesłanki: Guzek, Stefaniak (2016): 25-26.

19 Guzek, Stefaniak (2016): 26. 


\section{SPRZECZNOŚĆ KORZYŚCI Z PRZEDMIOTEM LUB CELEM USTAWY PODATKOWEJ LUB JEJ PRZEPISU}

Artykuł 119a $§ 1$ Ord. podat., w brzmieniu nadanym ustawa wprowadzającą klauzulę przeciwko unikaniu opodatkowania, odnosił się do korzyści podatkowej, sprzecznej w danych okolicznościach z przedmiotem i celem przepisu ustawy podatkowej. Nowelizacja, wedle projektodawcy ${ }^{20}$ motywowana dostosowaniem do dyrektywy ATA, odnosi się do „korzyści podatkowej [...] sprzecznej w danych okolicznościach z przedmiotem lub celem ustawy podatkowej lub jej przepisu. Należy się zgodzić z projektodawca, że art. 6 ust. 1 dyrektywy ATA odnosi się do „korzyści podatkowej sprzecznej z przedmiotem lub celem majacego zastosowanie prawa podatkowego", a więc posługuje się alternatywą łączną zamiast koniunkcji. Nowelizacja ma jednak charakter szerszy, niż wynikałoby to tylko z dyrektywy ATA. Podczas gdy w dyrektywie ATA i w pierwotnej wersji art. 119a § 1 Ord. podat. korzysta się z terminów „prawo podatkowe”, „przepis ustawy podatkowej”, tak w obecnie obowiązującej wersji klauzuli korzysta się z dwóch pojęć jednocześnie: „ustawa podatkowa lub jej przepis”.

Dokonując analizy logicznej obecnie obowiązującego przepisu i jego wcześniejszej wersji, należy stwierdzić, że opcje potencjalnej sprzeczności korzyści podatkowej z zastosowaniem prawa podatkowego wzrosły z jednej do czterech. Powyższe oznacza, że aby uznać korzyść podatkową za "sprzeczną z przedmiotem lub celem ustawy podatkowej lub jej przepisu”, wystarczy, aby korzyść podatkowa był sprzeczna alternatywnie z: przedmiotem ustawy podatkowej, przedmiotem przepisu ustawy podatkowej, celem ustawy podatkowej lub celem przepisu ustawy podatkowej. Tymczasem w kwantytatywnym ujęciu, wedle pierwotnej wersji przepisu, korzyść podatkowa mogła być uznana wyłącznie za sprzeczna z przedmiotem i celem przepisu ustawy podatkowej, a więc w jednym przypadku.

Powyższa zmiana prowadzi do sprzecznych poglądów w doktrynie. Niektórzy wskazuja, że wskutek wprowadzonych zmian ${ }^{21}$ „każda korzyść podatkowa, o ile będzie skutkiem zamierzonego i sztucznego sposobu działania, będzie kwalifikowana jako nieuprawniona, a tym samym przestanie pełnić funkcję dodatkowego kryterium definiujacego unikanie opodatkowania". Ustawa podatkowa zawiera bowiem w sobie $\mathrm{z}$ natury cel fiskalny ${ }^{22}$, a więc w przypadku każdej ustawy podatkowej znajdzie zastosowania rzeczona przesłanka zastosowania klauzuli przeciwko unikaniu opodatkowania. Takiej drodze rozumowania przeciwstawia się Hanna Filipczyk ${ }^{23}$, wskazując, że cel fiskalny ma charakter banalny, ponieważ wynika z istoty ustawy podatkowej. W związku z tym badaczka proponuje bardziej wysublimowane rozumienie ustawy uwidaczniające się w sprzężeniu celu ustawy z jej zasadami konstrukcyjnymi,

\footnotetext{
${ }^{20}$ Uzasadnienie projektu ustawy, druk nr 2860, Sejm VIII Kadencji: 57.

${ }^{21}$ Ladziński (2019): 25-26.

${ }^{22}$ Por. szerzej: Gomułowicz, Mączyński (2016): 350-351; Drozdowski (2018): 139-142.

${ }^{23}$ Filipczyk (2020): 30-33.
} 
np. opodatkowanie dochodu na gruncie ustaw o podatku dochodowym. W ocenie autorki: „korzyść polegająca na tym, że dochód pozostanie nieopodatkowany jest - w braku uzasadnienia zgodnego z celem szczególnego przepisu ustawy, ustanawiającego wyłączenie, zwolnienie lub ulgę - niezgodna z celem ustawy o podatku dochodowym" ${ }^{24}$. Akceptujac ten tok rozumowania w zakresie omawianych pojęć, polegający na ich dystynkcji przez zestawienie ze soba celu ustawy oraz celu przepisu ustawy podatkowej, należy wskazać, że nie rozwiązuje on problemu z zastosowaniem omawianej przesłanki w związku $\mathrm{z}$ występowaniem alternatywy łącznej w przepisie. Nieopodatkowanie dochodu ze względu na zwolnienie ustawowe (zgodność z celem przepisu) nadal będzie skutkować zastosowaniem przesłanki sprzeczności korzyści podatkowej z przedmiotem lub celem ustawy podatkowej.

Być może źródła tego problemu należy się doszukiwać w próbie naprawy pierwotnego brzmienia klauzuli, które podlegało krytyce w związku z zawarciem w art. 119a ust. 1 Ord. podat., wyłącznie pojęcia „sprzeczności z przedmiotem i celem przepisu ustawy podatkowej" ${ }^{25}$, podczas gdy unikanie opodatkowania ze swojej natury jest zgodne z litera poszczególnych przepisów podatkowych. Zalecenia Komisji, stanowiące prawzorzec klauzuli w brzmieniu nadanym ustawą wprowadzającą klauzulę przeciwko unikaniu opodatkowania, posługiwały się niespójnie różnymi pojęciami: w pkt 4.5 odnosiły się do przedmiotu, ducha i celu przepisów podatkowych, podczas gdy w preambule wspominały o „rozwiązaniach [...], które stoją w sprzeczności z intencją prawa”. Trafniejsze wydawałoby się posługiwanie jednym, pojemniejszym pojęciem od celu ustawy czy celu przepisu ustawy, jak występujace na gruncie dyrektywy ATA „mające zastosowanie prawo podatkowe” (applicable tax law, geltendes Stuerrecht) czy też „sprzeczność z intencją prawa” na gruncie Zalecenia Komisji. Co ciekawe, podobny termin „zgodne z prawem cele” pojawia się na gruncie art. 119c Ord. podat. (zob. szerzej niżej, pkt dotyczący sztuczności sposobu działania).

Problematyczne $^{26}$ jest również rozumienie przesłanki „sprzeczności z przedmiotem ustawy podatkowej lub jej przepisu”. Źródła takiego sformułowania można doszukiwać się w kalce językowej sformułowania „object and/ or purpose" występującego zarówno na gruncie anglojęzycznej wersji dyrektywy ATA, jak i innych podobnych klauzul (np. klauzuli celu głównego zawartej w art. 7 ust. 1 Konwencji MLI) ${ }^{27}$. Powyższe nie zwalnia jednak interpretatora z próby zrozumienia implementowanych do polskiego porządku prawnego pojęć. Niektórzy autorzy uznali to pojęcie za artefakt procesu legislacyjnego, który zawiera się w bardzo szerokim pojęciu „celu”, i w związku z tym jego pominięcie nie spowoduje strat $\mathrm{w}$ treści normatywnej ${ }^{28}$. Inni wskazywali wprost

24 Filipczyk (2020): 31.

25 Kujawski (2017): rozdział 6.1 pkt 9-13.

${ }^{26}$ Guzek, Stefaniak (2018): rozdz. II.1.2.2; Kondej (2018): 5-7; Filipczyk (2020): 29.

${ }^{27}$ Konwencja wielostronna implementująca środki traktatowego prawa podatkowego mające na celu zapobieganie erozji podstawy opodatkowania i przenoszeniu zysku, sporządzona w Paryżu dnia 24 listopada 2016 r., Dz. U. 2018, poz. 1369 (dalej jako: Konwencja MLI).

28 Filipczyk (2020): 29-30. 
na niezrozumiałość tego pojęcia ${ }^{29}$ albo podejmowali próby jego zrozumienia, tłumacząc, że przedmiot przepisu ustawy podatkowej może odnosić się alternatywnie do przedmiotu jako elementu konstrukcyjnego podatku ${ }^{30}$ albo przedmiotu jako zakresu regulacji danego przepisu ${ }^{31}$. W doktrynie spotykamy się więc ze skrajnymi poglądami dotyczącymi powyższego pojęcia rozciągającymi się od jego kompletnej niejasności, przez jego pomijalność w procesie wykładni, po różnorodne próby jego definiowania.

Podsumowując, przesłanka sprzeczności korzyści z przedmiotem lub celem ustawy podatkowej lub jej przepisu nie spełnia kryteriów postawionych przez TK. Zawiera zwroty niedookreślone, które budzą istotne kontrowersje w doktrynie, co nie gwarantuje ani jednolitość linii orzeczniczej decyzji stosowania prawa, ani braku udziału organów podatkowych w ustalaniu ich treści.

\section{SZTUCZNOŚĆ SPOSOBU DZIAŁANIA}

W obecnie obowiązujaccej ustawie nie zdefiniowano wprost sztuczności sposobu działania, ale posłużono się definicją negatywną. Zgodnie z art. 119c Ord. podat. na „niesztuczny” sposób działania składają się więc następujące elementy:

- na podstawie istniejaccych okoliczności należy przyjać, że podmiot działający rozsądnie zastosowałby ten sposób działania;

- na podstawie istniejących okoliczności należy przyjąć, że podmiot kierujący się zgodnymi z prawem celami zastosowałby ten sposób działania;

- sposób działania zostałby zastosowany przez wymieniony wyżej podmiot $\mathrm{w}$ dominującej mierze z uzasadnionych przyczyn ekonomicznych.

W jednej definicji ustawodawca zmieścił aż cztery zwroty niedookreślone odwołujące się: do „rozsądku”, do katalogu zgodnych z prawem celów i do sposobu działania w dominującej mierze z uzasadnionych przyczyn ekonomicznych. W przypadku ostatniego zwrotu „w dominujacej mierze z uzasadnionych przyczyn ekonomicznych" mamy do czynienia faktycznie z dwoma zwrotami niedookreślonymi: klauzulą generalną „z uzasadnionych przyczyn ekonomicznych” rozbudowaną o zwrot nieostry „w dominującej mierze”.

Człowiek rozsądny to „taki, która działa z rozwaga, robi coś z rozsądkiem, zastanawia się przed podjęciem decyzji, rozpoczęciem działania; roztropny, rozważny, rozumny” 32 , rozsądek zaś to „zdolność dojrzałego rozumienia świata, zjawisk, zależności między nimi, ludzi i spraw ludzkich" ${ }^{33}$. Nie ulega więc wątpliwości, że sformułowanie „podmiot działający rozsądnie” jest klauzula generalną odsyłająca do systemu ocen sytuującego się poza system prawnym.

\footnotetext{
${ }^{29}$ Nykiel (2019): pkt 2.

${ }^{30}$ Guzek, Stefaniak (2018): rozdział II.1.2.2

${ }^{31}$ Guzek, Stefaniak (2018): rozdział II.1.2.2; Kondej (2018): 5-7.

32 Słownik języka polskiego, <https://sjp.pl/rozs\%C4\%85dny> [dostęp: 5.05.2020].

33 Słownik języka polskiego, <https://sjp.pl/rozs\%C4\%85dek> [dostęp: 5.05.2020].
} 
Bardziej złożone wydaje się pojęcie „podmiot kierujący się zgodnymi z prawem celami”. Trudno trafnie sklasyfikować ten zwrot niedookreślony jako pojęcie nieostre czy klauzulę generalną, ponieważ nie istnieje ogólnodostępny katalog „zgodnych z prawem celów”. Czym innym byłoby bowiem odwołanie się do „podmiotu działajace zgodnie z prawem”, a czym innym jest „,kierowanie się zgodnymi z prawem celami”. W tym pierwszym przypadku nauka prawa dysponuje dość rozbudowanym instrumentarium wykładni prawa, pozwalającym odkodować normę prawna, które jednak okaże się nieprzydatne w przypadku ustalania celów zgodnych z prawem. Nie sposób nie zauważyć korelacji pomiędzy występujaccymi w omawianych przepisach zwrotami „korzyści podatkowej sprzecznej z przedmiotem lub celem ustawy podatkowej lub jej przepisu" a „zgodnymi z prawem celami”. Niemniej na gruncie koncepcji racjonalnego ustawodawcy użycie różnych pojęć przez ustawodawcę podatkowego rodzi wiele watpliwości. Po pierwsze, czy zgodne z prawem cele to cele ustawy podatkowej lub przepisu? Czy może zgodny z prawem cel należy do szerszego zbioru wykraczającego poza katalog celów przepisu lub ustawy? Po drugie, dlaczego ustawodawca operuje aż trzema pojęciami: przepisu, ustawy oraz prawa? Po trzecie, jeśli znaczenie tych pojęć miałoby być zbliżone lub tożsame, to dlaczego w drugim zdaniu art. $119 \mathrm{c} \S 1$ Ord. podat. ustawodawca wskazuje, że do uzasadnionych przyczyn ekonomicznych nie zalicza się celu osiagnięcia korzyści podatkowej sprzecznej z przedmiotem lub celem ustawy podatkowej lub jej przepisu, a więc wyraźnie te pojęcia rozróżnia? Powyższą wątpliwość wzmacnia pierwotne brzmienie art. 119c Ord. podat., w którym odwoływano się do podmiotu działającego rozsądnie i kierującego się zgodnymi z prawem celami innymi niż osiagnięcie korzyści podatkowej sprzecznej z przedmiotem i celem przepisu ustawy podatkowej. Ustawodawca podatkowy zestawiał więc wprost pojęcie zgodnych z prawem celów z pojęciem sprzeczności z przedmiotem i celem przepisu ustawy podatkowej. Obecnie obowiązujące przepisy w sposób odmienny zestawiaja je z uzasadnionymi przyczynami ekonomicznymi. Być może powyższa zmiana normatywna była próbą korekty innej wewnętrznej sprzeczności pierwotnie obowiąujących przepisów, które do zbioru zgodnych z prawem celów przez użycie sformułowania „innymi niž” zaliczały „osiagnięcie korzyści podatkowej sprzecznej z przedmiotem i celem przepisu ustawy podatkowej”.

Na koniec sformułowanie „w dominujaccej mierze z uzasadnionych przyczyn ekonomicznych" ma również charakter odesłania do kryterium pozaprawnego i z pewnością zbliża się najbardziej do pojęcia „nierzeczywistości”, o którym mowa w art. 6 ust. 1 dyrektywy ATA i orzecznictwie TSUE ${ }^{34}$, a także różnorodnych doktryn „ekonomicznej treści czynności” ${ }^{35}$. Niemniej pewien chaos pojęciowy wkrada się w art. 119c $§ 2$ Ord. podat. sugerujący, że na ocenę, iż sposób działania był sztuczny, może wskazywać w szczególności występowanie angażowania podmiotów pośredniczących mimo braku uzasadnienia ekonomiczne-

${ }^{34}$ Szerzej na temat m.in. przesłanki sztuczności w orzecznictwie TSUE zob. Majdowski (2016): 79-88.

${ }^{35}$ Por. amerykańską doktrynę economic substance: Olesińska (2013): 219-222 i niemiecka doktrynę Wirtschaftliche Betrachtungsweise: Lehner (1995): 237-249. 
go lub gospodarczego. Rozróżnienie pomiędzy pojęciami „,uzasadnione przyczyny ekonomiczne" a „uzasadnienie ekonomiczne" i "uzasadnienie gospodarcze” może okazać się nadzwyczaj trudne. Wedle projektodawcy ${ }^{36}$ przepisów pojęcie uzasadnienia gospodarczego ma się odnosić wyłącznie do osób prowadzących działalność gospodarcza, podczas gdy pojęcie uzasadnienia ekonomicznego powinno znaleźć zastosowanie do podmiotów nieprowadzących działalności gospodarczej. Uzasadnienie ekonomiczne i gospodarcze są rozdzielone spójnikiem „lub”, co sugeruje, że oba pojęcia należą do dwóch różnych zbiorów. Jest to o tyle zastanawiające, że zarówno pojęcie uzasadnienia ekonomicznego, jak i gospodarczego powinny się treściowo pokrywać z przesłanką „uzasadnionych przyczyn ekonomicznych”. Dodatkowo trudności interpretacyjne pogłębia wyeliminowanie podobnego rozróżnienia w obecnie obowiązującej wersji art. 119d Ord. podat. Konkludujacc, otwarty katalog z art. $119 \mathrm{c} \S 2 \mathrm{w}$ tym przypadku pogłębia wątpliwości interpretacyjne, zamiast je zawężać.

Podsumowując, w pierwszym zdaniu art. 119c Ord. podat. ust. 1 definicja pojęcia sztuczności sprowadziła się do zamiany jednego zwrotu niedookreślonego na cztery zwroty niedookreślone, w tym dwie klauzule generalne. Należy uznać, że zabieg ten oddalił nas, a nie przybliżył do spełnienia warunków postawionych przez TK.

\section{WNIOSKI}

Hipoteza obecnie obowiązujacej klauzuli przeciwko unikaniu opodatkowania nie spełnia kryteriów określonych w wyroku Trybunału Konstytucyjnego z 11 maja 2004 r. Materialnoprawne przesłanki zastosowania klauzuli zawarte w hipotezie normy daja pole do zindywidualizowanej interpretacji i nie gwarantują jednolitości linii orzeczniczej. Tym samym istnieje groźba nieprzewidywalności rozstrzygnięć podejmowanych na ich podstawie, a ustalenie ich treści może stać się udziałem organów stosujących te przepisy.

Wskutek implementacji wyroku TK nowa klauzula przeciwko unikaniu opodatkowania jest o wiele bardziej złożona i - niestety - bardziej niejasna od swojej poprzedniczki. Przesłanki zawarte w hipotezie, a w szczególności przesłanki sztucznego sposobu działania i głównego celu działania, przypominają mityczną Hydrę lernejska - ucięcie jednego łba (zwrotu niedookreślonego) owocuje pojawieniem się kolejnych dwóch lub trzech (a w przypadku naszej klauzuli - nawet czterech zwrotów niedookreślonych). Należy więc uznać, że nagromadzenie niejasności na gruncie obowiazującej klauzuli przeciwko unikaniu opodatkowania stanowi samoistną podstawę jej niekonstytucyjności na gruncie art. $2 \mathrm{w}$ zw. $\mathrm{z}$ art. 217 Konstytucji $\mathrm{RP}^{37}$.

${ }^{36}$ Uzasadnienie projektu ustawy, druk nr 367, Sejm VIII Kadencji: 28.

${ }^{37}$ Por. odmienny pogląd składu orzekającego wyrażony w wyroku NSA z 8 lipca 2109 r., II FSK 135/19, Centralna Baza Orzeczeń Sądów Administracyjnych, <http://orzeczenia.nsa.gov.pl/>. 
Jeszcze przed uchwaleniem ustawy wprowadzającej klauzulę przeciwko unikaniu opodatkowania Dominik Mączyński ${ }^{38}$ trafnie skonkludował, że nie jest „możliwe stworzenie ogólnej klauzuli obejścia prawa podatkowego z poszanowaniem wskazówek wynikających z uzasadnienia omawianego orzeczenia”. Eksperyment z klauzula w jej pierwotnym oraz obecnie obowiązujacym brzmieniu pozytywnie weryfikuje tę tezę. Tym samym należy stwierdzić, że wyrok TK, zrozumiały ze względu na chęć ochrony praw podatnika i specyficznego ducha czasu, był błędny ${ }^{39}$. Rację mieli sędziowie TK Marian Grzybowski, Adam Jamroz, Marek Mazurkiewicz i Bohdan Zdziennicki, którzy złożyli zdanie odrębne do tego orzeczenia. Natura klauzuli przeciwko unikaniu opodatkowania jest bowiem korzystanie ze zwrotów niedookreślonych, a ich dookreślenie wydrąża jej istotę. Tym samym spełnienie przesłanek postawionych przez TK oznaczałoby efektywną eliminację klauzuli przeciwko unikaniu opodatkowania z polskiego porządku prawnego. Próba dookreślania klauzuli przez pojęcia niedookreślone - jak w przypadku obowiązującej regulacji - prowadzi jedynie do mnożenia wątpliwości interpretacyjnych i rozszerza obszar niepewności prawnej.

Powyższe uwagi, choć kontrowersyjne w momencie, w którym waży się konstytucyjność obecnie obowiązującej klauzuli, są konieczne ze względu na manierę stanowienia prawa podatkowego w Polsce. Źródeł inflacji prawa podatkowego należy doszukiwać się również w oczekiwaniu od ustawodawcy podatkowego dookreślenia każdej instytucji prawa podatkowego, nawet takiej, która dookreślana być nie powinna.

W miejsce obecnie obowiazującej klauzuli przeciwko unikaniu opodatkowania należy wprowadzić zwarta klauzulę, biorąc za wzór objętość przywołanej w tekście klauzuli niemieckiej i uwzględniając wymogi unijne zawarte w art. 6 dyrektywy ATA. Zwięzła klauzula ma wiele większe szanse stać się stabilną instytucją prawa w przeciwieństwie do obecnie obowiązującej, która doczekała się już swojej nowelizacji. Nie zmienia to faktu, że podobnie jak pierwsza polska klauzula przeciwko unikaniu opodatkowania, tak i ta nie spełniałaby wyśrubowanych kryteriów określonych w wyroku TK z 11 maja $2004 \mathrm{r}$.

Prawa podatników zagwarantować powinna przede wszystkim budowa kultury prawnej opartej na zaufaniu pomiędzy podatnikiem a organami podatkowymi. Administracja powinna postrzegać interesy państwa nie tylko przez pryzmat krótkoterminowego wzrostu dochodów budżetowych, ale i ich utrzymania w dłuższym okresie przez ochronę źródła opodatkowania ${ }^{40}$. Przywołana wyżej tendencja dookreślania każdego pojęcia prawa podatkowego jest wyrazem głębokiej nieufności wobec państwa i uniemożliwia rozpoczęcie pro-

38 Mączyński (2014): 30.

${ }^{39} \mathrm{~W}$ innym orzeczeniu z tego okresu niedotyczącym materii podatkowej TK trafnie konstatował: bezwzględny zakaz posługiwania się określeniami nieostrymi prowadziłby do „niezrozumiałej kazuistyki”, a jednocześnie, że „nadmierna kazuistyka w konkretnych sytuacjach prowadzić może do deformacji idei państwa prawnego" - postanowienie TK z 27 kwietnia 2004 r., P 16/03, OTK-A 2004, nr 4, poz. 36.

${ }^{40}$ Gomułowicz (2013): 124-125. 
cesu budowania tego zaufania. Oczywiście brak zaufania pomiędzy podatnikami a organami podatkowymi w Polsce nie jest nieracjonalny i znajduje uzasadnienie w historii sporów podatkowych. Niemniej należy postawić pytanie, czy reakcja w postaci coraz to bardziej złożonych i kazuistycznych przepisów okazała się skutecznym remedium. Na koniec ostoją ochrony praw podatnika powinny być niezależne sądy, które będą ważyć dobro publiczne i prywatne, korygując ewentualne błędy administracji podatkowej.

Pewnym kierunkiem wzmacniajacym prawa podatnika są rozwiązania proceduralne w postaci opinii zabezpieczajacej czy opinii Rady do spraw Przeciwdziałania Unikaniu Opodatkowania. Można rozważać również inne koncepcje, jak przyspieszona procedura rozpatrywania spraw z zastosowaniem klauzuli przeciwko unikaniu opodatkowania, tak aby wykładnia zwrotów niedookreślonych była udziałem przede wszystkim sądów administracyjnych, a nie organów podatkowych. Być może należałoby rozważyć wprowadzenie analogicznej instytucji do art. 239d § 2 Ord. podat., polegajacej na wstrzymaniu wykonania decyzji w przypadku wniesienia skargi do sądu administracyjnego, chyba że wystapią kwalifikowane przesłanki podobne do uregulowanych w art. $239 d \S 1$ Ord. podat. Jest to jednak rozwiązanie skrajne i należy je wprowadzić wyłacznie, jeżeli rzetelne badania postlegislacyjne uzasadnia taką konieczność. Warto bowiem wskazać, że niektóre państwa decydują się na odwrotny mechanizm przyspieszający zapłatę podatku w związku z zastosowanie klauzuli przeciwko unikaniu opodatkowania ${ }^{41}$. Jest to również zrozumiałe, gdyż unikanie opodatkowania jako proceder naganny co do zasady nie powinno być uprzywilejowane, a w przypadkach wątpliwego zastosowania art. 119a Ord. podat. sądy powinny wstrzymać wykonanie takiej decyzji na zasadach ogólnych, na podstawie art. 61 ustawy z 30 sierpnia 2002 r. - Prawo o postępowaniu przed sądami administracyjnymi ${ }^{42}$.

Niemniej wszystkie te koncepcje będą miały poślednie znaczenie, jeśli nie zbuduje się wcześniej wspomnianej kultury zaufania pomiędzy organami podatkowymi i podatnikami, a dobrze funkcjonujące, niezależne sądy nie będą $\mathrm{w}$ odpowiednim terminie rozstrzygać sporów podatkowych.

\section{Edgar Drozdowski}

Uniwersytet im. Adama Mickiewicza w Poznaniu

edgar@amu.edu.pl

https://orcid.org/0000-0002-4029-0562

Bąkowska, K., Gniazdowski, M., Lachowicz, M. (2019). Horyzont optymalizacji - geneza, skala i struktura luki w podatku CIT. Warszawa.

Bergmans, A. (2016). The Principal Purpose Test: Comparison with EU-GAAR Initiatives, [w:] D.W. Blum, M. Seiler (eds.), Preventing Treaty Abuse. Vienna: 327-348.

Boniecka, M., Sołtysiak, P. (2018). Wybrane aspekty prawne i podatkowe dotyczące klauzuli PPT. Przegląd Podatkowy 10: 41-51.

${ }^{41}$ Filipczyk (2016): 16.

${ }^{42}$ Ustawa z 30 sierpnia 2002 r. - Prawo o postępowaniu przed sądami administracyjnymi, t.jedn.: Dz. U. 2019, poz. 2325. 
Dover, R., Ferrett, B., Gravino, D., Jones, E., Merler, S. (2015). Bringing Transparency, Coordination and Convergence to Corporate Tax Policies in the European Union. Part I: Assessment of the Magnitude of Aggressive Corporate Tax Planning. European Parliamentary Research Service. Brussels.

Drozdowski, E. (2018). Zasada zdolności płatniczej a polski system podatkowy. Poznań.

Filipczyk, H. (2016). Stosowanie klauzuli ogólnej przeciwko unikaniu opodatkowania - zagadnienia wybrane. Monitor Podatkowy 7: 13-18.

Filipczyk, H. (2020). „Sprzeczność z przedmiotem lub celem ustawy podatkowej lub jej przepisu” jako klauzulowa przesłanka unikania opodatkowania. Przegląd Podatkowy 3: 28-37.

Golecki, M.J. (2018). Klauzula w wybranych państwach UE, [w:] D.J. Gajewski (red.), Klauzula przeciwko unikaniu opodatkowania. Warszawa: 119-133.

Gomułowicz, A. (2013). Podatki a etyka. Warszawa.

Gomułowicz, A., Mączyński, D. (2016). Podatki i prawo podatkowe. Warszawa.

Guzek, M., Stefaniak, M. (2016). Klauzula przeciwko unikaniu opodatkowania. Monitor Podatkowy 11: 22-27.

Kondej, M. (2018). Sprzeczność korzyści z przedmiotem i celem przepisu ustawy podatkowej jako przesłanka stosowania klauzuli ogólnej przeciwko unikaniu opodatkowania. Polski Przegląd Nauk Społecznych: 3-16.

Kujawski, G. (2017). Klauzula generalna unikania opodatkowania. Lex/el.

Ladziński, A. (2019). Zmiany w ogólnej klauzuli przeciwko unikaniu opodatkowania - powrót do przeszłości. Przegląd Podatkowy 1: 22-28.

Lang, M. (2015). BEPS Action 6: Introducing an Antiabuse Rule in Tax Treaties. Tax Notes International 7: 655-664.

Lehner, M. (1995). Wirtschaftliche Betrachtungsweise und Besteuerung nach der wirtschaftlichen Leistungsfähigkeit, [w:] K. Tipke, J. Lang (Hrsg.), Die Steuerrechtsordnung in der Diskussion: Festschrift für Klaus Tipke. Westdeutscher Verlag: 237-249.

Majdowski, F. (2016). Zróżnicowane kryteria zwalczania zjawiska unikania opodatkowania w podatku dochodowym od osób prawnych. Zeszyty Naukowe Sądownictwa Administracyjnego 4(67): 73-88.

Majdowski, F. (2017). Principle Purpose Test - nowa klauzula antyabuzywna do zwalczania nadużycia umów o unikaniu podwójnego opodatkowania. Niewygodne (i zapomniane) pytania. Monitor Podatkowy 11: 25-31.

Mączyński, D. (2014). Wpływ orzecznictwa Trybunału Konstytucyjnego na trwałość instytucji materialnego prawa podatkowego. Ruch Prawniczy, Ekonomiczny i Socjologiczny 76(3): 20-36.

Moreno, A.B. (2017). GAARs and treaties: from the guiding principle to the principal purpose test. What have we gained from BEPS Action 6? Intertax 45(6/7): 432-446.

Nykiel, W. (2019). Nowe przepisy dotyczące klauzuli przeciw unikaniu opodatkowania - wybrane aspekty legislacyjne, [w]: J. Głuchowski (red.), Współczesne problemy prawa podatkowego teoria i praktyka. Księga jubileuszowa dedykowana Profesorowi Bogumiłowi Brzezińskiemu. Tom 1. Warszawa: 382-391.

Olesińska, A. (2013). Klauzula ogólna przeciwko unikaniu opodatkowania. Toruń.

Piekarz, R., Miarkowski, A. (2015). Znikające miliardy. Jak transfer dochodów za granicę drenuje polski budżet. Centrum Analiz Klubu Jagiellońskiego.

Taboada, C.P. (2015). OECD base erosion and profit shifting Action 6: the general anti-abuse rule. Bulletin for International Taxation 69(10): 602-608.

\section{THE LERNAEAN HYDRA - ON THE IMPOSSIBILITY OF ACCOMMODATING THE CONSTITUTIONAL TRIBUNAL'S JUDGMENT AND THE GENERAL ANTI-AVOIDANCE RULE}

\section{Sum mary}

This article sets forth the following argument: the legal norm hypothesis of the general antiavoidance rule (hereinafter: GAAR) does not conform to the terms set out by Constitutional Tribunal in the judgment of 11 May 2004 (case no. K 4/03). The new regulation failed to specify the 
premises for the application of GAAR in accordance with the Constitutional Tribunal's requirements. The new GAAR is more complex and unfortunately more convoluted than its predecessor, placing it at odds with Article 2 in conjunction with Article 217 of the Constitution of the Republic of Poland. The conclusions of the article indicate that it is impossible to create a GAAR that conforms to the terms set out by Constitutional Tribunal, as this would effectively entail the elimination of the GAAR from the Polish legal system. In place of the current GAAR, a new GAAR should be implemented - similar in scope to the German GAAR and compliant with the requirements set out in Article 6 of the ATA Directive. Taxpayers' rights should be guaranteed by the culture of trust established between the taxpayer and the tax administration, the independent judiciary and specific procedural solutions.

Keywords: general anti-avoidance rule; GAAR; constitutionality 
